\title{
Synthesis of highly 1,3-proton shift transferable $N$-benzyl imines of trifluoroacetophenone under the "low-basicity" reaction conditions
}

\author{
Dmitrii O. Berbasov, Ifeyinwa D. Ojemaye, Vadim A. Soloshonok \\ Department of Chemistry and Biochemistry, University of Oklahoma, 620 Parrington Oval, Room 208, Norman, OK 73019, USA
}

Received 21 October 2003; accepted 17 November 2003

\begin{abstract}
The standard reaction conditions commonly used for the condensation of carbonyl compounds with amines were found to be synthetically inefficient for preparation of the imines derived from trifluoroacetophenone and benzylamines owing to the susceptibility of these imines to 1,3-proton shift. Application of a "low-basicity" method, using instead of free benzylamines their salts formed from acetic acid (AA), allowed synthesis of the target compounds in chemically pure form and excellent chemical yields.
\end{abstract}

(C) 2004 Elsevier B.V. All rights reserved.

Keywords: 1,3-Proton shift reaction; Imines; Operationally convenient conditions; Fluorine and compounds

\section{Introduction}

$\alpha$-Trifluoromethyl containing amines A (Fig. 1) represent one of the most synthetically powerful fluorine-containing building block-synthons in modern organic chemistry. For instance, the SciFinder search for the fixed structure B (Fig. 1) yielded more than 11,466 compounds and 2204 references, which is truly remarkable considering that all of these derivatives are purely synthetic. This unique interest in chemistry of $\alpha$-trifluoromethyl containing amino-compounds is driven mostly by agricultural and pharmaceutical industries ${ }^{1}$ using the structural motif $\mathbf{B}$ as a pharmacophore unit in the design of new generations of fungicides, pesticides, herbicides, desiccants, defoliants, insecticides, arthropodicides, microbicides, selective antibacterial agents, therapeutic agents/probes, enzyme inhibitors, enzyme receptor antagonists/agonists [1-4]. There is also significant continued interest in fluorinated amino-compounds in the area of material science, in particular, in the development of new electroluminescent devices and liquid crystals [1-4]. An emerging and quite exciting area, so far stemming from a purely academic interest in fluorinated amino-compounds, is the application of their chiral and enantiomerically pure derivatives as chiral internal/external ligands, auxiliaries, and

\footnotetext{
${ }^{*}$ Corresponding author. Tel.: +1-405-325-8279; fax: +1-405-325-6111. E-mail address: vadim@ou.edu (V.A. Soloshonok).

${ }^{1}$ More than $90 \%$ of the references retrieved by SciFinder are patents, a fact manifesting the remarkable industrial interest in this class of compounds.
}

catalysts for general asymmetric synthesis [2b,3,4e,4f,4h]. For instance, taking into account a uniquely vide range of various synthetic applications of $\alpha$-phenylethylamine (Fig. 2) and its derivatives in the modern asymmetric synthesis [5], the synthetic potential offered by its enantiomerically pure trifluoro-analog $\mathbf{1}$, wherein the trifluoromethyl might play the role of a stereodirecting group, is enormous $[2 b, 4,6]$.

Taking into account the importance of $\alpha$-trifluoromethyl (and more generally, perfluoroalkyl/aryl) containing amines, as discussed above, it is not surprising that the development of synthetic methods for preparing these compounds has been the focus of numerous research groups $[4,7-14,16,17]$ (see also footnote 2). The vast variety of the approaches available in the literature can be divided into the following methods: (a) a conventional (with application of external reducing reagents) reductive amination of the corresponding trifluoromethyl ketones [7]; (b) a nucleophilic addition of alkyl groups (Grignard reagents, sulfoxide-stabilized carbanions) to $\alpha$-trifluoromethyl-imines [8] or hydrazones [9]; (c) reactions of the trifluoromethyl-imines [10]; (d) a nucleophilic addition of trimethyl(trifluoromethyl)silane to nitrones [11] or imines [12]; (e) a reduction or nucleophilic opening of fluoral-derived 1,3-oxazolidines [13]; (f) elaboration of trifluoroacetimidoyl halides [14].

For quite some time, we have been developing a new method conceptually different from the methods listed above. This method avoids the use of conventional reducing reagents but results in a product corresponding to a reductive 


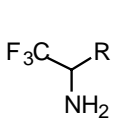

(A)

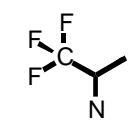

(B)
Fig. 1. General structure $\alpha$-trifluoromethyl containing amino compounds (A), and fixed structure (B) used for the SciFinder search.

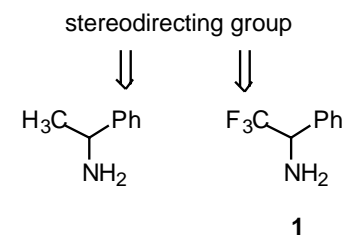

Fig. 2. $\alpha$-Phenylethylamine its trifluoro-analog $\mathbf{1}$.

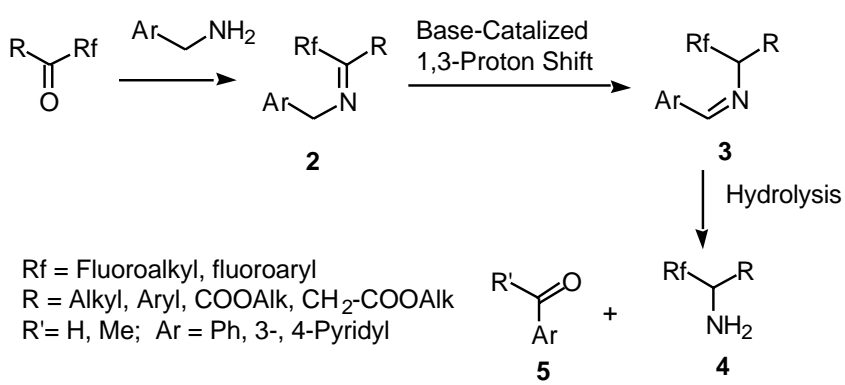

Scheme 1. Biomimetic, conventional reducing reagent-free reductive amination of carbonyl compounds.

amination of fluorocarbonyl compounds to the corresponding fluorine-containing amines and amino acids (Scheme 1). This approach, mimicking biological transamination [15], represents the most ideal solution to the reductive amination of carbonyl compounds (Scheme 1) making use of the intramolecular reduction-oxidation process via a base-catalyzed 1,3-proton shift in the azaallylic system of azomethines (imines) 2. We were the first to demonstrate that the presence of electron-withdrawing perfluoroalkyl or perfluoroaryl groups in $\alpha$-position to the imine function in derivatives 2 makes their base-catalyzed isomerization to Schiff bases $\mathbf{3}$ virtually irreversible and thus synthetically useful. Products 3 can be easily hydrolyzed under mild acidic conditions giving rise to a readily separable mixture of the target fluorinated amino 4 and carbonyl 5 compounds. The synthetic advantage of this biomimetic approach over the literature methods is its generality and operational convenience. ${ }^{2}$ Previously we reported an efficient applica-

\footnotetext{
${ }^{2}$ A concept of the "Atom Economy" introduced by Professor Barry M. Trost has found quick and unanimous understanding, support and appreciation in the chemistry community as a philosophical guideline for the development of organic synthesis in 21st century. On the other hand, in the current literature one can notice another trend shaping a paradigm of the synthetic methodology of the future, which is simplicity of experimental conditions, or as we prefer to call it, operationally convenient reaction conditions.
}

tion of this biomimetic approach for preparation of fluorinecontaining amines [16], $\alpha$ - and $\beta$-amino acids [17] starting from readily available fluorinated aldehydes and ketones, or $\alpha$ - and $\beta$-keto carboxylic acids, respectively. Our most recent achievement in this area is the development of double-PSR methodology for a direct, one-pot conventional reducing reagent-free transformation of perfluoroalkyl-carboxylic acids to the corresponding $\alpha, \alpha$-dihydroperfluoroalkylamines [18]. Of particular interest are the results reported by other research groups on application of the PSR methodology for transamination of fluorine-free carbonyl compounds to the corresponding amino-derivatives [19] as well as the preparation of fluorine-containing phosphorus analogs of $\alpha$ - and $\beta$-amino acids [20].

\section{Results and discussion}

As a part of our current project on the development of catalytic version of the asymmetric PSR method, we needed a series of non-enaminolizable $N$-benzyl imines of trifluoroacetophenone 8a-d (Scheme 2). The method previously reported by us [16b] for preparation of imine 7a involves the standard condensation reaction conditions between trifluoroacetophenone (6) and benzylamine (7a) using $p$-tolylsulphonic acid ( $p$-TSA) as a catalyst, toluene as a solvent and a Dean-Stark trap to remove the produced water. While this method is operationally simple it is, unfortunately, not synthetically efficient, allowing preparation of the target imine 8a in only moderate chemical yield (up to 68\%) and involving tedious purification by flash-chromatography. The major drawback of this reaction conditions is that, during the reaction, the imine 8a easily undergoes 1,3-proton shift isomerization to give Schiff base 9a (Table 1, entry 1). Due to the similarity between structures 8a and 9a their separation is difficult. Moreover, some $10 \%$ of other byproducts were observed in the crude mixture by ${ }^{19} \mathrm{~F}$ NMR. Similar results were obtained in the reactions of ketone $\mathbf{6}$ with benzylamines $\mathbf{7 b}-\mathbf{d}$, having electron releasing (entries 2 and 3) and electron-withdrawing (entry 4) substituents on the phenyl ring. As expected, [16c,16d] the largest amount of the isomerized product $9 \mathbf{d}$ was observed in the reaction of the trifluoromethyl derivative $\mathbf{7 d}$, giving rise to an almost 1:1 mixture of imines $8 \mathbf{d}$ and $9 \mathbf{d}$. The isomerization of $8 \mathbf{a}-\mathbf{d}$ to 9a-d could be catalyzed by the benzylamine remaining in the reaction mixture acting as a base, or, taking into account the reaction high temperature, the transformation may be a

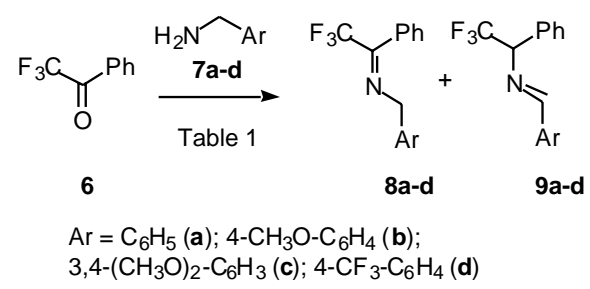

Scheme 2. 
Table 1

Reactions of trifluoroacetophenone 6 with amines $7 \mathbf{a}-\mathbf{d}$. Synthesis of imines 8a-d (Scheme 2) ${ }^{\mathrm{a}}$

\begin{tabular}{|c|c|c|c|c|c|c|}
\hline Entry & $7 a-d$ & Solvent & Method $^{\mathrm{b}}$ & $\begin{array}{l}T \\
\text { (h) }\end{array}$ & $\begin{array}{l}\text { Yield } \\
\%\end{array}$ & $\begin{array}{l}\text { Ratio }^{c} \\
8 / 9\end{array}$ \\
\hline 1 & $\mathbf{a}$ & Toluene & $\mathrm{A}$ & 9 & 87 & $71 / 29$ \\
\hline 2 & b & Toluene & A & 9 & 85 & $67 / 33$ \\
\hline 3 & c & Toluene & A & 9 & 86 & $66 / 34$ \\
\hline 4 & d & Toluene & A & 9 & 41 & $56 / 44$ \\
\hline 5 & $\mathbf{a}$ & Benzene & A & 16 & 90 & $61 / 39$ \\
\hline 6 & $\mathbf{a}$ & Chloroform & A & 22 & 96 & $74 / 26$ \\
\hline 7 & $\mathbf{a}$ & Toluene & B & 1 & 96 & $85 / 15$ \\
\hline 8 & c & Toluene & B & 1 & 97 & $97 / 3$ \\
\hline 9 & $\mathbf{a}$ & Benzene & B & 3 & 94 & $>98 / 2$ \\
\hline 10 & b & Benzene & B & 3 & 95 & $>98 / 2$ \\
\hline 11 & c & Benzene & B & 3 & 96 & $>98 / 2$ \\
\hline 12 & d & Benzene & B & 3 & 92 & $90 / 10$ \\
\hline 13 & $\mathbf{a}$ & Chloroform & B & 20 & 97 & $>99 / 1$ \\
\hline 14 & b & Chloroform & B & 20 & 94 & $>99 / 1$ \\
\hline 15 & c & Chloroform & B & 20 & 97 & $>99 / 1$ \\
\hline 16 & d & Chloroform & B & 20 & 96 & $>99 / 1$ \\
\hline
\end{tabular}

${ }^{a}$ All reactions were conducted at reflux in the indicated solvent.

${ }^{\mathrm{b}}$ Method A: ketone 6 ( 1 equivalent), amine 7 (1.1 equivalent), $p$-TSA (0.1 equivalent). Method B: ketone 6 ( 1 equivalent), amine 7 (1.1 equivalent), acetic acid (1.1 equivalent).

${ }^{\mathrm{c}}$ Determined by ${ }^{19} \mathrm{~F}$ NMR $(300 \mathrm{MHz})$ analysis of the crude reaction mixtures.

thermally induced process. To determine the cause of the 1,3-proton shift under these reaction conditions we conducted two experiments. Thus, after refluxing of pure imine 8a in toluene for several hours it was isolated intact, while addition of benzylamine (catalytic amounts: $10 \mathrm{~mol} \%$ ) to a solution of $\mathbf{8 a}$ in toluene, even at room temperature, resulted in fast isomerization of imine $\mathbf{8 a}$ to Schiff base $\mathbf{9 a}$. Furthermore, even though we found that the reaction temperature had a noticeable effect on the rate of imine $\mathbf{8 a}$ formation, its influence on the isomerization and ratio of products $8 \mathbf{a}$ and 9a was rather insignificant. Thus, the reactions between ketone 6 and benzylamine 7a, conducted in benzene (entry 5 ) and chloroform (entry 6) were much slower giving rise to a mixture of $8 \mathbf{a}$ and $9 \mathbf{a}$ in a ratio comparable with that observed in reaction conducted in toluene (entry 1).

Having analyzed the data obtained, we concluded that the $p$-TSA-catalyzed condensation conditions are incompatible with the high susceptibility of the target imines 8 to $1,3-$ proton-shift. Therefore, we decided to try the "low-basicity" reaction conditions recently reported by us [21]. These conditions, consisting in the reaction of a carbonyl compound with a salt of amine and acetic or trifluoroacetic acid, were originally developed for the preparation of imines derived form highly electrophilic and polyfunctional fluorinated carbonyl compounds. For example, application of the corresponding salts of benzylamine, instead of benzylamine and catalytic amounts of $p$-TSA, allowed us to exclude the haloform-type decomposition of polyfluorinated carbonyl compounds as well as to dramatically improve the chemoand regio-selectivity in the reactions of fluorinated $\alpha$ - and $\beta$-keto esters.
First, we conducted the reaction of ketone 6 with acetic acid (AA) salts of benzylamines $7 \mathbf{a}, \mathbf{c}(\mathbf{7 a}-\mathbf{A A})$ using toluene as a solvent. We found that the reactions occurred with remarkably increased rates and chemical yields (entries 7 and 8) giving rise to a mixture of 8a,c and 9a,c, however. Even though we did not obtain the desired result, preparation of pure imines $\mathbf{8}$, the substantially improved ratio of products 8a,c and 9a,c was quite encouraging. Using benzene as a solvent for the reactions of ketone $\mathbf{6}$ with salts $\mathbf{7 a - d - A A}$ decreased the reaction rates, but further increased the ratio of 8a-d and 9a-d (entries 9-12) to an almost satisfactory level of $>98 / 2$, except for the reaction of the trifluoromethyl derivative 9d (entry 12). Finally, we carried out the reactions in chloroform. To our satisfaction in all cases (entries 13-16) we observed clean and complete conversion of ketone $\mathbf{6}$ giving rise to only the target imines $\mathbf{8 a}-\mathbf{d}$, which could be isolated chemically pure and in excellent yields.

\section{Conclusion}

In summary, we found that the standard reaction conditions commonly used for the condensation of carbonyl compounds with amines are synthetically inefficient for preparation of the target imines derived from trifluoroacetophenone and benzylamines. On the other hand, application of the "low-basicity" method, using instead of free benzylamines their salts with acetic acid, allowed synthesis of the target compounds in chemically pure form suitable for catalytic and kinetic studies.

\section{Experimental}

\subsection{General}

Unless otherwise noted, all reagents and solvents were obtained from commercial suppliers and used without further purification. All the reactions were carried out in a regular atmosphere without any special caution to exclude air. Unless indicated, ${ }^{1} \mathrm{H},{ }^{19} \mathrm{~F}$, and ${ }^{13} \mathrm{C}$ NMR spectra, were taken in $\mathrm{CDCl}_{3}$ solutions at 299.95, 282.24, and $75.42 \mathrm{MHz}$, respectively, on an instrument in the University of Oklahoma NMR Spectroscopy Laboratory. Chemical shifts refer to TMS and $\mathrm{CFCl}_{3}$ as the internal standards.

Yields refer to isolated yields of products of greater than $95 \%$ purity as estimated by ${ }^{1} \mathrm{H}$ and ${ }^{19} \mathrm{~F}$ NMR spectrometry. All new compounds were characterized by ${ }^{1} \mathrm{H},{ }^{19} \mathrm{~F},{ }^{13} \mathrm{C}$ NMR and mass spectrometry.

\subsection{Typical procedure for preparing imines $8 \boldsymbol{8}-\boldsymbol{d}$}

\subsubsection{N-(1-Phenyl-2,2,2-trifluoroethylidene)benzylamine}

(8a) $[16 b]$

A solution of ketone $6(5.000 \mathrm{~g}, 28.88 \mathrm{mmol})$ in $5 \mathrm{ml}$ of chloroform was added at room temperature to a solution of 
benzylamine $(3.714 \mathrm{~g}, \quad 34.66 \mathrm{mmol})$ and acetic acid $(2.080 \mathrm{~g}, 34.66 \mathrm{mmol})$ in chloroform $(20 \mathrm{ml})$. The resultant mixture was refluxed until the reaction was completed $(20 \mathrm{~h}$, monitored by ${ }^{19} \mathrm{~F}$ NMR).

Yields of imines 8a-d are listed in Table 1 (entries 13-16).

\subsection{2. $N$-( $1^{\prime}$-Phenyl-2' $, 2^{\prime}, 2^{\prime}$-trifluoroethylidene $)-4$ -}

methoxybenzylamine $(\boldsymbol{8 b})$

${ }^{1} \mathrm{H}$ NMR: $\delta 7.47(\mathrm{~m}, 3 \mathrm{H}), 7.28(\mathrm{~m}, 2 \mathrm{H}), 7.16(\mathrm{~d}$, $J=8.1 \mathrm{~Hz}, 2 \mathrm{H}), 6.86(\mathrm{~d}, J=8.1 \mathrm{~Hz}, 2 \mathrm{H}), 4.54(\mathrm{~s}, 2 \mathrm{H})$, 3.77 (s, 3H). ${ }^{19} \mathrm{~F}$ NMR: $\delta-71.36$ (s). ${ }^{13} \mathrm{C}$ NMR: $\delta$ 158.76, $158.55(\mathrm{q}, J=32.3 \mathrm{~Hz}), 131.94,130.17,130.03,128.84$, $128.80,127.63,119.71(\mathrm{q}, J=278.7 \mathrm{~Hz}), 113.95,56.31$, 55.17 .

\subsection{3. $N$-( $1^{\prime}$-Phenyl-2' $2^{\prime}, 2^{\prime}$-trifluoroethylidene $)-3,4-$ dimethoxybenzylamine $(8 \mathrm{c})$}

${ }^{1} \mathrm{H}$ NMR: $\delta 7.51(\mathrm{dd}, J=2.1,4.8 \mathrm{~Hz}, 2 \mathrm{H}), 7.28(\mathrm{~m}, 3 \mathrm{H})$, $6.83(\mathrm{~d}, J=3 \mathrm{~Hz}, 1 \mathrm{H}), 6.80(\mathrm{~s}, 1 \mathrm{H}), 6.74(\mathrm{dd}, J=2.1$, $7.8 \mathrm{~Hz}, 1 \mathrm{H}), 4.55$ (s, 2H), $3.87(\mathrm{~s}, 3 \mathrm{H}), 3.86(\mathrm{~s}, 3 \mathrm{H}) .{ }^{19} \mathrm{~F}$ NMR: $\delta-71.40(\mathrm{~s}) .{ }^{13} \mathrm{C}$ NMR: $\delta 158.71(\mathrm{q}, J=33.9 \mathrm{~Hz})$, $149.00,148.17,130.50,130.21,129.99,128.86,127.65$, $119.68(\mathrm{q}, J=278.7 \mathrm{~Hz}), 119.67,111.12,110.94,56.55$, $55.87,55.79$.

\subsection{4. $N$ - $\left(1^{\prime}\right.$-Phenyl-2' $, 2^{\prime}, 2^{\prime}$-trifluoroethylidene $)-4$ - (trifluoromethyl)benzylamine $(8 \boldsymbol{d})$}

${ }^{1} \mathrm{H}$ NMR: $\delta 7.59(\mathrm{~d}, J=8.1 \mathrm{~Hz}, 2 \mathrm{H}), 7.52(\mathrm{~m}, 3 \mathrm{H}), 7.39$ $(\mathrm{d}, J=8.1 \mathrm{~Hz}, 2 \mathrm{H}), 7.27$ (m, 2H), 4.65 (s, 2H). ${ }^{19} \mathrm{~F}$ NMR: $\delta$ -63.00 (s), -71.47 (s). ${ }^{13} \mathrm{C}$ NMR: $\delta$ 164.37, $159.80(\mathrm{q}$, $J=34.3 \mathrm{~Hz}), 142.03,130.46,129.99,129.04,127.78$, $127.49,125.52(\mathrm{q}, J=3.7 \mathrm{~Hz}), 125.51(\mathrm{q}, J=272.1 \mathrm{~Hz})$, $119.58(\mathrm{q}, J=278.6 \mathrm{~Hz}), 56.20$.

Schiff bases 9a-d, isolated as by-products, can be easily prepared from 8a-d under the general conditions described previously for synthesis 9a [16b]. Spectral characteristics of 9b-d are listed below.

\subsubsection{N-4'-Methoxybenzylidene-1-phenyl-2,2,2- trifluoroethylamine $(\mathbf{9 b})$}

${ }^{1} \mathrm{H}$ NMR: $\delta 8.25(\mathrm{~s}, 1 \mathrm{H}), 7.74(\mathrm{~d}, J=9.0 \mathrm{~Hz}, 2 \mathrm{H}), 7.55(\mathrm{~d}$, $J=6.3 \mathrm{~Hz}, 2 \mathrm{H}), 7.33(\mathrm{~m}, 3 \mathrm{H}), 6.88(\mathrm{~d}, J=9.0 \mathrm{~Hz}, 2 \mathrm{H})$, $4.73(\mathrm{q}, J=7.5 \mathrm{~Hz}, 1 \mathrm{H}), 3.75(\mathrm{~s}, 3 \mathrm{H}) .{ }^{19} \mathrm{~F}$ NMR: $\delta-74.28$ $(\mathrm{d}, J=7.9 \mathrm{~Hz}) .{ }^{13} \mathrm{C}$ NMR: $\delta$ 164.99, 162.37, 135.24, $130.44,128.78,128.74,128.50,128.27,124.81$ (q, $J=280.7 \mathrm{~Hz}), 113.98,74.96(\mathrm{q}, J=28.2 \mathrm{~Hz}), 55.23$.

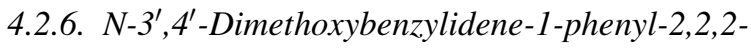
trifluoroethylamine $(9 \mathrm{c})$

${ }^{1} \mathrm{H}$ NMR: $\delta 8.25$ (s, 1H), $7.55(\mathrm{~m}, 3 \mathrm{H}), 7.37(\mathrm{~m}, 3 \mathrm{H}), 7.19$ $(\mathrm{dd}, J=1.8,8.4 \mathrm{~Hz}, 1 \mathrm{H}), 6.82(\mathrm{~d}, J=11.1 \mathrm{~Hz}, 1 \mathrm{H}), 4.76$ $(\mathrm{q}, J=8.1 \mathrm{~Hz}, 1 \mathrm{H}), 3.91(\mathrm{~s}, 3 \mathrm{H}), 3.86(\mathrm{~s}, 3 \mathrm{H}) .{ }^{19} \mathrm{~F}$ NMR: $\delta$ $-74.17(\mathrm{~d}, J=5.9 \mathrm{~Hz}) .{ }^{13} \mathrm{C}$ NMR: $\delta 165.14,152.04$, $149.21,135.09,131.52,128.65,128.51,128.43,124.21$ $(\mathrm{q}, \quad J=281.0 \mathrm{~Hz}), 123.96,110.20,109.02,74.81 \quad(\mathrm{q}$, $J=28.2 \mathrm{~Hz}), 55.74$.
4.2.7. N-4'-Trifluoromethybenzylidene-1-phenyl-2,2,2trifluoroethylamine $(\mathbf{9 d})$

${ }^{1} \mathrm{H} \mathrm{NMR}: \delta 8.43(\mathrm{~s}, 1 \mathrm{H}), 7.95(\mathrm{~d}, J=7.8 \mathrm{~Hz}, 2 \mathrm{H}), 7.69(\mathrm{~d}$, $J=7.5 \mathrm{~Hz}, 2 \mathrm{H}), 7.54(\mathrm{~d}, J=5.1 \mathrm{~Hz}, 2 \mathrm{H}), 7.40(\mathrm{~m}, 3 \mathrm{H})$, $4.84(\mathrm{q}, J=6 \mathrm{~Hz}, 1 \mathrm{H}) .{ }^{19} \mathrm{~F}$ NMR: $\delta-63.43(\mathrm{~s}),-74.36(\mathrm{~d}$, $J=7.9 \mathrm{~Hz}) .{ }^{13} \mathrm{C}$ NMR: $\delta 164.38,138.29,134.51,129.41$, $129.12,129.00,128.83,128.74,128.69,128.62$ (q, $J=272.0 \mathrm{~Hz}), \quad 125.65, \quad(\mathrm{q}, \quad J=3.7 \mathrm{~Hz}), \quad 75.05 \quad(\mathrm{q}$, $J=28.7 \mathrm{~Hz})$.

\section{Acknowledgements}

This work was supported by the start-up fund provided by the Department of Chemistry and Biochemistry, University of Oklahoma.

\section{References}

[1] (a) For recent, excellently edited and comprehensive monographs on synthesis and application of fluoro-organic compounds in general and fluorine-containing amino-compounds in particular, see: R. Filler, Y. Kobayashi, L.M. Yagupolskii (Eds.), Organofluorine in Medicinal Chemistry and Biochemical Applications, Elsevier, Amsterdam, The Netherlands, 1993;

(b) I. Ojima, J.R. McCarthy, J.T. Welch (Eds.), Biomedical Frontiers of Fluorine Chemistry, American Chemical Society, Washington, DC, 1996;

(c) R.D. Chambers (Ed.), Topics in Current Chemistry-Organofluorine Chemistry: Techniques and Synthons, vol. 193, Springer, Berlin, Germany, 1997;

(d) R.E. Banks, B.E. Smart, J.C. Tatlow, Organofluorine Chemistry: Principles and Commercial Applications, Plenum Press, New York, 1994;

(e) M. Hudlicky, A.E. Pavlath, Chemistry of Organic Fluorine Compounds II. A Critical Review, ACS Monograph 187, American Chemical Society, Washington, DC, 1995.

[2] (a) For comprehensive reviews on fluorine-containing amino acids and asymmetric synthesis of fluorinated compounds, see: V.P. Kukhar, V.A. Soloshonok, (Eds.) Fluorine-Containing Amino Acids, Wiley, Chichester, UK, 1994;

(b) V.A. Soloshonok (Ed.), Enantiocontrolled Synthesis of FluoroOrganic Compounds: Stereochemical Challenges and Biomedicinal Targets, Wiley, Chichester, UK, 1999.

[3] (a) T. Hayashi, V.A. Soloshonok (Eds.), Enantiocontrolled Synthesis of Fluoro-Organic Compounds, Tetrahedron: Asymmetry Special Issue, Tetrahedron: Asymmetry 5 (6) (1994). (b) G. Resnati, V.A. Soloshonok, (Eds.), Fluoroorganic Chemistry: Synthetic Challenges and Biomedical Rewards, Tetrahedron Symposium-in-Print No. 58. Tetrahedron 52 (1996) 1-330.

[4] (a) For recent leading publications on synthesis and application of $\alpha$ trifluoromethyl containing amines, see:J. Legros, F. Meyer, M. Coliboeuf, B. Crousse, D. Bonnet-Delpon, J.-P. Begue, J. Org. Chem. 68 (2003) 6444;

(b) F. Gagosz, S.Z. Zard, Org. Lett. 5 (2003) 2655;

(c) B. Torok, S.G.K. Prakash, Adv. Synth. Catal. 245 (2003) 165;

(d) Y. Gong, K. Kato, H. Kimoto, Bull. Chem. Soc. Jpn. 75 (2002) 2637;

(e) K. Funabiki, M. Nagamori, M. Matsui, D. Enders, Synthesis 17 (2002) 2585;

(f) A. Volonterio, P. Bravo, W. Panzeri, C. Pesenti, M. Zanda, Eur. J. Org. Chem. 19 (2002) 3336; 
(g) Y. Gong, K. Kato, J. Fluorine Chem. 116 (2002) 103;

(h) T. Katagiri, Y. Fujiwara, S. Takahashi, N. Ozaki, K. Uneyama, Chem. Commun. 9 (2002) 986;

(i) W.B. Motherwell, L. Storey, J. Synlett 4 (2002) 646;

(j) N. Lebouvier, C. Laroche, F. Huguenot, T. Brigaud, Tetrahedron Lett. 43 (2002) 2827;

(k) F. Levrat, H. Stoeckli-Evans, N. Engel, Tetrahedron: Asymmetry 13 (2002) 2335.

[5] (a) For reviews on the use of $(R)$ - and $(S)$ - $\alpha$-phenylethylamine in asymmetric synthesis, see:E. Juaristi, J. Escalante, J.L. León-Romo, A. Reyes, Tetrahedron: Asymmetry 9 (1998) 715;

(b) E. Juaristi, J.L. León-Romo, A. Reyes, Escalante J. Tetrahedron: Asymmetry 10 (1999) 2441.

[6] (a) Steric bulk and stereocontrolling properties of trifluoromethyl group, as well as fluorine-containing substituents, are still controversial issues. For some discussions, see:V.A. Soloshonok, D.V. Avilov, V.P. Kukhar, Tetrahedron 52 (1996) 12433;

(b) V.A. Soloshonok, A.D. Kacharov, D.V. Avilov, T. Hayashi, Tetrahedron Lett. 37 (1996) 7845;

(c) V.A. Soloshonok, A.D. Kacharov, D.V. Avilov, K. Ishikawa, N. Nagashima, T. Hayashi, J. Org. Chem. 62 (1997) 3470.

[7] (a) K. Kato, Y. Gong, T. Saito, H. Kimoto, Enantiomer 5 (2000) 521 ;

(b) S. Watanabe, T. Fujita, M. Sakamoto, H. Hamano, T. Kitazume, T. Yamazaki, J. Fluorine Chem. 83 (1997) 15.

[8] (a) A. Ishii, K. Higashiyama, K. Mikami, Synlett 12 (1997) 1381; (b) P. Bravo, F. Guidetti, F. Viani, M. Zanda, A.L. Markovsky, A.E. Sorochinsky, I.V. Soloshonok, V.A. Soloshonok, Tetrahedron 54 (1998) 12789.

[9] D. Enders, K. Funabiki, Org. Lett. 3 (2001) 1575.

[10] I. Kumadaki, S. Jonoshita, A. Harada, M. Omote, A. Ando, J. Fluorine Chem. 97 (1999) 61.

[11] D.W. Nelson, R.A. Easley, B.N.V. Pintea, Tetrahedron Lett. 40 (1999) 25.

[12] (a) J.C. Blazejewski, E. Anselmi, M.P. Wilmshurst, Tetrahedron Lett. 40 (1999) 5475;

(b) G.K.S. Prakash, M. Mandal, G.A. Olah, Synlett 1 (2001) 77;

(c) G.K.S. Prakash, M. Mandal, G.A. Olah, Angew. Chem. Int. Ed. 40 (2001) 589;

(d) G.K.S. Prakash, M. Mandal, G.A. Olah, Org. Lett. 3 (2001) 2847.

[13] (a) A. Ishii, F. Miyamoto, K. Higashiyama, K. Mikami, Tetrahedron Lett. 39 (1998) 1199;

(b) A. Ishii, F. Miyamoto, K. Higashiyama, K. Mikami, Chem. Lett. 2 (1998) 119.

[14] K. Uneyama, J. Fluorine Chem. 97 (1999) 11.

[15] (a) A.E. Braunstein, M.G. Kritsmann, Biochimiya 2 (242) (1937) 859 ;

(b) E.E. Snell, in: P.M. Fasella, A.E. Braunstein, A. Rossi-Fanelli, (Eds.), Chemical and Biological Aspects of Pyridoxal Catalysis, Macmillan, New York, 1963, pp. 1-12; (c) E.E. Snell, A.E. Braunstein, E.S. Severin, Y.M. Torchinsky (Eds.), Pyridoxal Catalysis: Enzymes and Model Systems, Interscience, New York, 1968;

(d) W.P. Jencks, Catalysis in Chemistry and Enzymology, McGrawHill, New York, 1969, pp. 143-145;

(e) B.M. Guirard, E.E. Snell, in: M. Florkin, E.H. Stotz, (Eds.) Comprehensive Biochemistry, vol. 15, Elsevier, New York, 1964, Chapter 5;

(f) T.C. Bruice, S.J. Benkovic, Bioorganic Mechanisms, vol. 2, W.A. Benjamin, New York, 1966, Chapter 8.

[16] (a) For preparation of fluorine-containing amines using PSR methodology see:V.A. Soloshonok, A.G. Kirilenko, V.P. Kukhar, G. Resnati, Tetrahedron Lett. 35 (1994) 3119;

(b) T. Ono, V.A. Soloshonok, Kukhar, J. Org. Chem. 61 (1996) 6563;

(c) V.A. Soloshonok, T. Ono, Synlett 9 (1996) 919-921;

(d) V.A. Soloshonok, T. Ono, Tetrahedron 52 (1996) 14701;

(e) V.A. Soloshonok, T. Ono, J. Org. Chem. 62 (1997) 3030

[17] (a) For preparation of fluorine-containing $\alpha$ - and $\beta$-amino acids using PSR methodology see:V.A. Soloshonok, A.G. Kirilenko, V.P. Kukhar, G. Resnati, Tetrahedron Lett. 34 (1993) 3621;

(b) V.A. Soloshonok, A.G. Kirilenko, S.V. Galushko, V.P. Kukhar, Tetrahedron Lett. 35 (1994) 5063;

(c) V.A. Soloshonok, A.G. Kirilenko, N.A. Fokina, I.P. Shishkina, S.V. Galushko, V.P. Kukhar, V.K. Svedas, E.V. Kozlova, Tetrahedron Asymmetry 5 (1994) 1119;

(d) V.A. Soloshonok, A.G. Kirilenko, N.A. Fokina, S.V. Galushko, V.P. Kukhar, V.K. Svedas, G. Resnati, Tetrahedron: Asymmetry 5 (1994) 1225 ;

(e) V.A. Soloshonok, V.P. Kukhar, Tetrahedron 52 (1996) 6953;

(f) V.A. Soloshonok, V.P. Kukhar, Tetrahedron 53 (1997) 8307;

(g) V.A. Soloshonok, T. Ono, I.V. Soloshonok, J. Org. Chem. 62 (1997) 7538 ;

(h) V.A. Soloshonok, I.V. Soloshonok, V.P. Kukhar, V.K. Svedas, J. Org. Chem. 63 (1998) 1878.

[18] V.A. Soloshonok, H. Ohkura, K. Uneyama, Tetrahedron Lett. 43 (2002) 5449.

[19] (a) For application of PSR methodology for preparing fluorine-free amino-compounds see:W.G.H. Johannes, V.G. Johannes, N.J.M. Roeland, Z. Binne, Tetrahedron Lett. 36 (1995) 3917;

(b) G. Cainelli, D. Giacomini, A. Trere, P.P. Boyl, J. Org. Chem. 61 (1996) 5134;

(c) A. Hjelmencrantz, U. Berg, J. Org. Chem. 67 (2002) 3585

[20] (a) For application of PSR methodology for preparing fluorinated Pamino acids see:Y. Chengye, Youji Huaxue 21 (2001) 862;

(b) X. Jingbo, Y. Chengye, Heteroatom Chem. 11 (2000) 541;

(c) X. Jingbo, Z. Xiaomei, Y. Chengye, Heteroatom Chem. 11 (2000) 536.

[21] (a) For application of PSR methodology for preparing fluorinated Pamino acids see:H. Ohkura, D.O. Berbasov, V.A. Soloshonok, Tetrahedron 59 (2003) 1647;

(b) D.O. Berbasov, V.A. Soloshonok, Synthesis 13 (2003) 2005. 